\title{
Mineralization potentials of aromatic hydrocarbons by estuarine microorganisms: variations with season, location, and bacterioplankton production
}

\author{
John P. Hudak*, Julie McDaniel, SangHoon Lee, Jed A. Fuhrman** \\ Marine Sciences Research Center, S.U.N.Y. at Stony Brook, Stony Brook, New York 11794-5000, USA
}

\begin{abstract}
Mineralization of ${ }^{14} \mathrm{C}$ labeled pentachlorophenol (PCP) and 2 polycyclic aromatic hydrocarbons $(\mathrm{PAH})$, naphthalene and phenanthrene, to ${ }^{14} \mathrm{CO}_{2}$ by surface water microorganisms was assessed in samples collected from a relatively unpolluted Long Island Sound station (USA) in midsummer and at various points in the lower Hudson River Estuary from September to June. PCP mineralization was always low, $<5 \mathrm{ng} \mathrm{l}^{-1} \mathrm{~d}^{-1}$, at both sites. Highest rates of naphthalene and phenanthrene mineralization, when corrected for volatilization during experiments, were $118 \% \mathrm{~d}^{-1}$ $\left(5.8 \mu \mathrm{g} \mathrm{l}^{-1} \mathrm{~d}^{-1}\right)$ and $65 \% \mathrm{~d}^{-1}\left(3.2 \mu \mathrm{g} \mathrm{l}^{-1} \mathrm{~d}^{-1}\right)$, respectively, in Long Island Sound to $172 \% \mathrm{~d}^{-1}(1.72 \mu \mathrm{g}$ $\left.\mathrm{l}^{-1} \mathrm{~d}^{-1}\right)$ and $87 \% \mathrm{~d}^{-1}\left(0.87 \mu \mathrm{g} \mathrm{l}^{-1} \mathrm{~d}^{-1}\right)$ in the Hudson River Estuary. PAH mineralization and bacterioplankton production rates, measured with $\left[{ }^{3} \mathrm{H}\right]$ thymidine incorporation, increased dramatically downstream from the northern tip of Manhattan Island to the Verrazano Narrows. Phenanthrene mineralization and bacterioplankton production rates in the Hudson were highest in summer. Bacterial cell abundance usually increased downstream and was at its highest level during June, but overall correlated poorly to bacterioplankton production and pollutant mineralization. The high rates of $\mathrm{PAH}$ mineralization and bacterial production near New York Harbor are probably supported by the high inputs of petroleum hydrocarbons and sewage in the region. Total bacterioplankton activity and biomass may be less important than the composition of the bacterioplankton population in determining the extent of naphthalene and phenanthrene biodegradation.
\end{abstract}

\section{INTRODUCTION}

The presence of municipal wastewater facilities, harbors, and industry have historically made estuarine waterways sites of accumulation for a wide variety of organic pollutants (Knap et al. 1979, Huggett \& Bender 1980, Connell 1982, Readman et al. 1982, DeLaune et al. 1983, Brown et al. 1985). Previous work has suggested that microbial degradation can be an important mechanism for the removal of organic contaminants from the aquatic environment (Herbes \& Schwall 1978, Sherril \& Sayler 1980, Readman et al. 1982, DeLaune et al. 1983). Although sediment bacteria often play an

\footnotetext{
- Present address: South Central Connecticut Regional Water Authority, 90 Sargent Drive, New Haven, Connecticut 06511-5966, USA

- Addressee for correspondence
}

important role in this process, periods of anoxia along with toxic levels of pollutants in sediments may limit biodegradation (Bauer \& Capone 1985a, b). It is therefore important to examine the potential for biodegradation in the water column as well, and how it may vary with season, location within an estuary, and bacterial growth and biomass.

We examined the biodegradation potential of naphthalene and phenanthrene, which are low molecular weight polycyclic aromatic hydrocarbons, and pentachlorophenol (PCP), a widely used chlorinated pesticide. The widespread occurrence of these compounds in aquatic environments has been well documented (Pierce \& Victor 1978, Neff 1979). They are all relatively soluble in water $\left(>1 \mathrm{mg} \mathrm{l}^{-1}\right)$, which makes them more likely to be found in the water column. ${ }^{14} \mathrm{C}$-labeled pollutants were used to assess their potential for biodegradation by monitoring their mineralization to 
${ }^{14} \mathrm{CO}_{2}$ ) and uptake by planktonic microorganisms. Uptake and mineralization experiments were first carried out using seawater collected from a relatively pristine Long Island Sound station. Pollutant mineralization, heterotrophic bacterioplankton production, and bacterial abundance were studied in the Hudson River Estuary during a series of cruises from September 1985 through June 1986. The Hudson River Estuary is an ideal representative of a contaminated site due to its history of organic pollution (Connell 1982, Mueller et al. 1982, Brown et al. 1985).

\section{MATERIALS AND METHODS}

Long Island Sound experiments. In August 1985, Long Island Sound seawater samples (salinity $=28 \%$ ) were collected in acid washed plastic bottles from a pebble beach at Crane Neck Point, New York $140^{\circ}$ $55.3^{\prime} \mathrm{N}, 73^{\circ} 09.3^{\prime} \mathrm{W}$ ), a relatively pristine area of Long Island Sound with no industry or harbors in the immediate vicinity. Freshly collected seawater, divided into live and autoclaved control batches (600 to $700 \mathrm{ml}$ ), received radiolabeled pollutant via syringe in $\leq 9 \mu \mathrm{l}$ acetone carrier (final pollutant concentration $=5 \mu \mathrm{g}$ $\left.1^{-1}\right)$. Labeled pollutants were $\left[1,(4,5,8)-{ }^{14} \mathrm{C}\right]$ naphthalene, $5 \mathrm{mCi} \mathrm{mmol}^{-1}$ (97\% pure, Amersham Corp., Arlington Heights, Ill. $),\left[9-{ }^{14} \mathrm{C}\right]$ phenanthrene, $21.5 \mathrm{mCi}$ $\mathrm{mmol}^{-1}$, and $\left[\mathrm{U}-{ }^{14} \mathrm{C}\right]$ pentachlorophenol, $10.57 \mathrm{mCi}$ $\mathrm{mmol}^{-1}$ (both $98 \%$ pure, Pathfinder Laboratories Inc., St. Louis, Mo.). Samples $(15 \mathrm{ml})$ for mineralization measurements from both batches were dispensed into 4 sets (1 set per timepoint of 10,24,48, and $72 \mathrm{~h}$ ) of triplicate glass $25 \times 100 \mathrm{~mm}$ culture tubes (KIMAX). The tubes were stoppered with teflon lined septa and put into a gyratory water bath in the dark at $21^{\circ} \mathrm{C}$. Uptake measurements used 4 additional sets of tubes. Four tubes per batch ( 1 tube per timepoint) were used for monitoring total ${ }^{14} \mathrm{C}$ radioactivity through the course of each experiment to check for losses.

${ }^{14} \mathrm{C}$-pollutant mineralization experiments were terminated by the addition of $50 \mu$ l of $2.4 \mathrm{~N} \mathrm{H}_{2} \mathrm{SO}_{4}$ (final $\mathrm{pH}=2$ ) via syringe through the septa, ${ }^{14} \mathrm{CO}_{2}$ was collected by placing a $9 \mathrm{~cm}$ influent and $2 \mathrm{~cm}$ effluent syringe needles through the septa and bubbling with compressed air for 20 min, to flush remaining ${ }^{14} \mathrm{CO}_{2}$ out of the water and into the headspace (volume ca $30 \mathrm{ml}$ ). Effluent gas was passed through a scintillation vial containing $10 \mathrm{ml}$ of a $\mathrm{CO}_{2}$ absorbing scintillation cocktail (Oxosol- ${ }^{14} \mathrm{C}$, National Diagnostics, Somerville, NJ). Radioactivity was measured with an LKB-Wallac 1217 Rack Beta scintillation counter, with sample quench determined via external standards. The live incubation results were corrected for volatile ${ }^{14} \mathrm{C}$ absorption by subtracting the radioactivity measured in killed controls. ${ }^{14} \mathrm{CO}_{2}$ recovery efficiency of this system, determined using $\left[{ }^{14} \mathrm{C}\right]$ bicarbonate, was found to be $100 \%$.

Uptake of ${ }^{14} \mathrm{C}$-pollutants was quantified at each timepoint by filtering $15 \mathrm{ml}$ samples through a $25 \mathrm{~mm}$ diameter, $0.45 \mu \mathrm{m}$ pore size Millipore filter (Type HA; Millipore Corp., Bedford, Mass., USA). The filters were rinsed 15 times with $1 \mathrm{ml}$ of filter sterilized seawater and placed in a glass scintillation vial with $1 \mathrm{ml}$ of ethyl acetate to dissolve the filter. Radioactivity was quantified following additions of $5 \mathrm{ml}$ of NEN 963 scintillation cocktail (New England Nuclear Corp., Boston, Mass.). Radioactivity measured in killed control samples was subtracted from the live uptake values.

Hudson River Estuary study. Work was done on 5 cruises from September 1985 through June 1986 in the lower Hudson River and its associated estuary (Fig. 1).

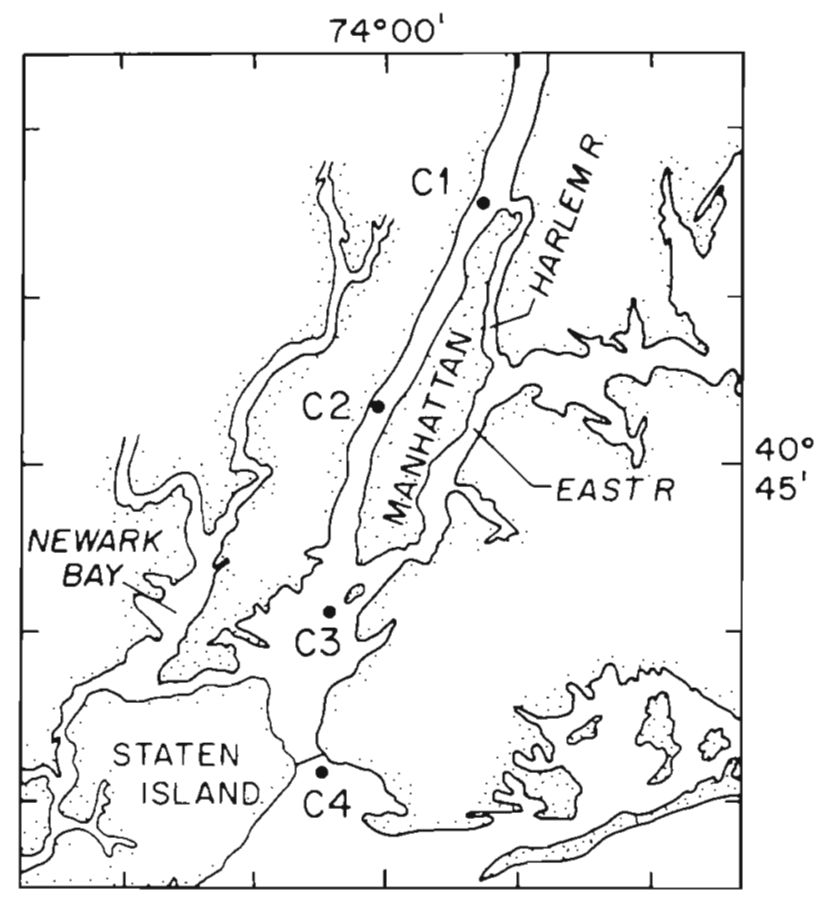

Fig. 1. Hudson River Estuary study area and sampling sites

Surface water samples were collected with a 51 Niskin bottle. For pollutant mineralization measurements, subsamples $(75 \mathrm{ml}$ ) of live and boiled (killed control) water samples were dispensed into separate $250 \mathrm{ml}$ Ehrlenmeyer flasks before receiving an addition of ${ }^{14} \mathrm{C}$ pollutant in $5 \mu \mathrm{l}$ acetone (final pollutant concentration $=1 \mu \mathrm{g} \mathrm{l}^{-1}$ ). Triplicate $15 \mathrm{ml}$ samples from each of the 2 flasks were dispensed into glass culture tubes, sealed with teflon lined septa, and incubated in the dark at approximate in situ temperature for $24 \mathrm{~h}$.

Incorporation of ${ }^{3} \mathrm{H}$ thymidine (TdR) into macromolecules was measured according to the methods of 
Fuhrman \& Azam (1982). Triplicate $20 \mathrm{ml}$ samples were dispensed into clean, sterile $50 \mathrm{ml}$ plastic centrifuge tubes. Killed controls received $0.2 \mathrm{ml}$ of borate buffered formalin. Samples were incubated for $30 \mathrm{~min}$ at in situ temperature with $5 \mathrm{nM}$ [methyl $-{ }^{3} \mathrm{H}$ ]thymidine $(80.2 \mathrm{Ci}$ $\mathrm{mmol}^{-1}$; New England Nuclear Corp., Boston, Mass.) Incubations were terminated with $20 \mathrm{ml}$ of ice cold $10 \%$ trichloroacetic acid. After a 10 min extraction period, samples were filtered onto a $0.45 \mu \mathrm{m}$ pore size Millipore filter, and the radioactivity was measured as for the pollutant uptake studies. Heterotrophic bacterioplankton production estimates were calculated with the assumptions that each mole of thymidine incorporated represents $2 \times 10^{18}$ cells produced (Fuhrman \& Azam 1982) and each bacterial cell contains $2 \times 10^{-14} \mathrm{~g} \mathrm{C}$ (Lee \& Fuhrman 1987).

Bacterial cells were enumerated from samples preserved with $5 \%$ borate-buffered formalin with the acridine orange direct count method (Hobbie et al. 1977). At least 10 fields of 20 or more bacteria were counted per slide on an Olympus $\mathrm{BH}-2$ microscope (1250 $\times$ magnification) equipped with an FITC filter set and a mercury burner lamp.

\section{RESULTS}

\section{Long Island Sound experiments}

Of the PAH, $23 \%$ of the added naphthalene appeared as ${ }^{14} \mathrm{CO}_{2}$ in the first day, and only $4 \%$ more in the subsequent $2 d ; 43 \%$ of the phenanthrene appeared as ${ }^{14} \mathrm{CO}_{2}$ in the first day, and an additional $13 \%$ in the next $2 \mathrm{~d}$. Statistical analysis of these uncorrected log transformed data using Students $t$-test indicated that naphthalene and phenanthrene mineralization was significant at all timepoints $(p<0.001)$ when compared with killed controls. It appeared that phenanthrene was more efficiently mineralized than naphthalene, but this was probably an artifact of the more rapid volatilization of naphthalene (the volatilized PAHs were able to enter or pass through the rubber stoppers). In killed controls, naphthalene volatilized $15.8 \% \mathrm{~h}^{-1}$ while phenanthrene volatilized at $1.8 \% \mathrm{~h}^{-1}$. We tried to correct the mineralization measurements for PAH volatilization with the equation:

$$
{ }^{14} \mathrm{CO}_{2}=\mathrm{S}_{\mathrm{o}} \cdot \mathrm{K}_{\mathrm{bio}} \cdot\left(1-\mathrm{e}^{-\mathrm{t}\left(\mathrm{K}_{\mathrm{bio}}+\mathrm{K}_{\mathrm{vol}}\right)}\right) /\left(\mathrm{K}_{\mathrm{bio}}+\mathrm{K}_{\mathrm{vol}}\right)
$$

where $\mathrm{S}_{\mathrm{o}}=$ initial amount of substrate; $\mathrm{K}_{\mathrm{b}_{10}}$ and $\mathrm{K}_{\mathrm{vol}}=$ rate constants of biological mineralization and volatilization, respectively; $\mathrm{t}=$ elapsed time $(\mathrm{h})$. This yielded mineralization rates of $117.6 \% \mathrm{~d}^{-1}\left(5.76 \mu \mathrm{gl}^{-1} \mathrm{~d}^{-1}\right)$ and $64.8 \% \mathrm{~d}^{-1}\left(3.12 \mathrm{\mu g} \mathrm{l}^{-1} \mathrm{~d}^{-1}\right)$ for naphthalene and phenanthrene, respectively.
Significant $\left[{ }^{14} \mathrm{C}\right]$ naphthalene uptake was observed at all time points, reaching a maximum of $4.4 \%$ of initially added naphthalene at $24 \mathrm{~h}$, and then declining for the remainder of the study. The amount of $\left[{ }^{14} \mathrm{C}\right]$ phenanthrene appearing on the $>0.45$ fraction of live samples was never significantly higher than in autoclaved controls, but high control values (probably adsorption) may have masked any uptake.

Mineralization of $\left[{ }^{14} \mathrm{C}\right] \mathrm{PCP}$ was so low $(0.1 \%$, or $5 \mathrm{ng}$ $1^{-1}$ in the first day) that all of the ${ }^{14} \mathrm{CO}_{2}$ could have been produced from contaminants in the labeled stock solution. Therefore, even though the results were statistically significant $(p<0.05)$, they represent a maximum estimate. No significant uptake of PCP was observed at any time during the experiment.

\section{Hudson River Estuary cruises}

Results from the 5 Hudson River Estuary cruises are shown in Table 1. On all 5 dates studies, the biodegradation potentials of PAH (mostly phenanthrene and in 1 case naphthalene) increased from the northern tip of Manhattan Island (C1) downstream to the Verranzano Narrows (C4). As in the Long Island Sound samples, the rate of PCP mineralization was slow, and it showed no clear differences between stations $\mathrm{C} 1$ and $\mathrm{C} 4$.

Both phenanthrene mineralization rates and heterotrophic bacterial production were highest in the September and June cruises and declined in the winter months. In general, bacterioplankton production in surface waters increased downstream, with the exception of the June 1986 cruise, which followed $2 \mathrm{~d}$ of heavy rainfall. Thus, this reversal in bacterial productivity may have been fueled by runoff upstream or higher inputs of untreated sewage due to overloaded wastewater treatment plants. Bacterial abundance showed a general, but inconsistent, trend increasing downstream and was at its highest level during the June 1986 cruise. Abundance varied over a much smaller range than did production, both between locations and between months (Table 1).

\section{DISCUSSION}

The significant rates of phenanthrene and naphthalene mineralization in all the locations studied support other findings which suggest that the ability to degrade petroleum hydrocarbons is widespread in the marine environment (Buckley et al. 1976). The phenanthrene mineralization rate in the Long Island Sound samples nearly equalled those in summer samples from New York Harbor (C3) and the Verranzano Narrows (C4), despite the history of petroleum contamination at 
Table 1. Hudson River Estuary results

\begin{tabular}{|c|c|c|c|c|c|c|c|c|}
\hline \multirow[t]{2}{*}{ Date } & \multirow[t]{2}{*}{$\begin{array}{l}\text { Compound } \\
\text { tested }\end{array}$} & \multirow[t]{2}{*}{ Site } & \multirow[t]{2}{*}{$\begin{array}{l}\text { Sal. } \\
(\% \circ)\end{array}$} & \multirow[t]{2}{*}{$\begin{array}{l}\text { Temp. } \\
\left({ }^{\circ} \mathrm{C}\right)\end{array}$} & \multicolumn{2}{|c|}{$\begin{array}{c}\text { Mineralization }{ }^{a b} \\
\left(\because, d^{-1}\right)\end{array}$} & \multirow{2}{*}{$\begin{array}{c}\text { Bacterial } \\
\text { production } \\
\left(\mu g \mathrm{Cl}^{-1} \mathrm{~d}^{-1}\right)\end{array}$} & \multirow{2}{*}{$\begin{array}{c}\text { Bacterial } \\
\text { abundance } \\
\left(10^{9} \text { cells } I^{-1}\right)\end{array}$} \\
\hline & & & & & Apparent & Corrected $^{c}$ & & \\
\hline \multirow[t]{2}{*}{ Sep 85} & PCP & $\begin{array}{l}\mathrm{C} 1 \\
\mathrm{C} 4\end{array}$ & $\begin{array}{l}13.3 \\
25.3\end{array}$ & $\begin{array}{l}21.2 \\
20.8\end{array}$ & $\begin{array}{l}0.45(0.05) \\
0.36(0.09)\end{array}$ & $-\alpha$ & $\begin{array}{r}20(0.0) \\
129(3.0)\end{array}$ & $\begin{array}{l}3.3 \\
4.3\end{array}$ \\
\hline & Phe & $\begin{array}{l}\mathrm{C} 1 \\
\mathrm{C} 4\end{array}$ & $\begin{array}{l}13.3 \\
25.3\end{array}$ & $\begin{array}{l}21.2 \\
20.8\end{array}$ & $\begin{array}{l}16.3(4.5) \\
48.3(2.0)\end{array}$ & $\begin{array}{l}22.2 \cdots \\
86.0 \cdots\end{array}$ & $\begin{array}{r}20(0.0) \\
129(3.0)\end{array}$ & $\begin{array}{l}3.3 \\
4.3\end{array}$ \\
\hline Oct 85 & Nap & $\begin{array}{l}\mathrm{C} 1 \\
\mathrm{C} 4\end{array}$ & $\begin{array}{r}8.9 \\
22.0\end{array}$ & $\begin{array}{l}16.2 \\
16.6\end{array}$ & $\begin{array}{r}4.6(0.16) \\
31.2(0.18)\end{array}$ & $\begin{array}{r}18.6^{\cdots} \\
172.4^{\cdots}\end{array}$ & $\begin{array}{l}17(2.0) \\
60(1.0)\end{array}$ & $\begin{array}{l}3.6 \\
3.2\end{array}$ \\
\hline Nov 85 & Phe & $\begin{array}{l}\mathrm{C} 1 \\
\mathrm{C} 4\end{array}$ & $\begin{array}{r}7.3 \\
18.3\end{array}$ & $\begin{array}{l}11.8 \\
12.8\end{array}$ & $\begin{array}{r}0.9(0.30) \\
25.7(0.60)\end{array}$ & $\begin{array}{r}1.1 \cdots \\
37.4 \cdots\end{array}$ & $\begin{array}{r}8(0.0) \\
52(7.0)\end{array}$ & $\begin{array}{l}3.4 \\
3.8\end{array}$ \\
\hline Jan 86 & Phe & $\begin{array}{l}\mathrm{C} 1 \\
\mathrm{C} 2 \\
\mathrm{C} 3 \\
\mathrm{C} 4\end{array}$ & $\begin{array}{r}4.7 \\
10.7 \\
23.9 \\
21.4\end{array}$ & $\begin{array}{l}2.5 \\
2.4 \\
3.8 \\
3.3\end{array}$ & $\begin{array}{c}1.7(0.10) \\
6.5(0.28) \\
20.1(1.4) \\
22.1(0.15)\end{array}$ & $\begin{array}{r}2.1 \cdots \\
8.3 \cdots \\
28.1 \cdots \\
31.3 \cdots\end{array}$ & $\begin{array}{r}9(0.0) \\
25(1.0) \\
68(8.0) \\
61(1.0)\end{array}$ & $\begin{array}{l}2.5 \\
2.9 \\
4.0 \\
3.9\end{array}$ \\
\hline Jun 86 & Phe & $\begin{array}{l}\mathrm{C} 1 \\
\mathrm{C} 2 \\
\mathrm{C} 3\end{array}$ & $\begin{array}{r}8.0 \\
10.0 \\
15.0\end{array}$ & $\begin{array}{l}22.2 \\
21.9 \\
18.4\end{array}$ & $\begin{array}{l}15.1(0.70) \\
28.8(1.2) \\
48.6(1.4)\end{array}$ & $\begin{array}{l}20.4 \cdots \\
42.9 \cdots \\
86.8 \cdots\end{array}$ & $\begin{array}{r}175(4.0) \\
143(6.0) \\
89(1.1)\end{array}$ & $\begin{array}{l}6.3 \\
6.0 \\
8.0\end{array}$ \\
\hline $\begin{array}{l}\text { a Standa } \\
\text { b Final c } \\
{ }^{c} \text { Correc } \\
{ }^{d} \text { Volatil }\end{array}$ & $\begin{array}{l}\text { leviation in } \\
\text { entration of } \\
\text { for volatiliza } \\
\text { ion insignific }\end{array}$ & $\begin{array}{l}\text { renth } \\
\text { lluta } \\
\text { n of } \\
\text { it }\end{array}$ & $\begin{array}{l}\text { ed }= \\
\text { bstra }\end{array}$ & $\begin{array}{l}\text { by } 1^{-1} \\
\text { by }\end{array}$ & cance vs $k$ & controls, & $\cdots p<0.00$ & Student's $t$-test \\
\hline
\end{tabular}

the latter sites. In terms of total mass degraded, the Long Island Sound rates were higher than the Hudson rates because 5 times as much phenanthrene was added in those experiments. The PCP mineralization rates were small, probably because of the high chlorine content in the PCP molecule. Substantial degradation of PCP has been observed in other studies but only after long lag periods (DeLaune et al. 1983, Pignatello et al. 1983). Short incubation periods were used in this study in order to minimize changes in bacterial community structure which can occur during sample containment (Ferguson et al. 1984).

Within the Hudson River Estuary there were large spatial differences in the mineralization of naphthalene and phenanthrene. The lowest rates of mineralization always occurred at the most upstream station (C1) whereas the highest rates were found in the vicinity of New York Harbor (C3 and C4). In most cases bacterioplankton production followed this trend as well, with the exception of the June 1986 cruise. The failure for the trend in phenanthrene biodegradation to reverse as well suggests that total bacterial activity is not the sole microbiological factor in determining degradation rates. It has been previously reported that areas with high degrees of petroleum hydrocarbon contamination contain a higher percentage of petroleum hydrocarbon utilizers making up the bacterial community (Walker \& Colwell 1975, Roubal \& Atlas 1978). The major area of PAH accumulation in the Hudson lies in the New York
Harbor and lower bay region, with the major sources including oil spills, sewer overflows, municipal wastes, and urban runoff (O'Connor et al. 1982). Thus, the high mineralization rates at Stations C2 and C3 (compared to C1) found in the June 1986 cruise, in spite of lower bacterioplankton production, may have been facilitated by a higher percentage of bacteria in the population capable of degrading phenanthrene.

The high concentration of municipal wastewater treatment plants in the New York metropolitan region probably aids in supporting the high rates of biodegradation and bacterioplankton production at Stations C3 and $\mathrm{C} 4$, by providing organic and inorganic nutrients. It has been estimated that about 3 billion gallons (ca 12 $\times 10^{9}$ l) of treated and untreated wastewater enter New York Harbor daily (O'Connor \& Mueller 1984). The rates of bacterial production measured here (Table 1) suggest a bacterial organic consumption rate that may approach or exceed local primary production as measured in previous years (Malone 1976). Therefore it seems likely that the bacterioplankton population relies significantly on outside sources for organic carbon, such as sewage and runoff. In addition, inputs of nitrogen and phosphorus from these sources may account for the higher pollutant degradation rates in the lower estuary. These nutrients appear to play an important role in pollutant biodegradation and their supply may limit biodegradation during summer (Ward \& Brock 1976, Roubal \& Atlas 1978, Cooney et al. 1985). 
Phenanthrene mineralization and bacterial production in the Hudson River Estuary declined with the onset of colder temperatures. Temperature has been shown to be the primary limiting factor for biodegradation in several aquatic systems during the winter (Ward \& Brock 1976, Roubal \& Atlas 1978, Bartholomew \& Pfaender 1983, Cooney et al. 1985), and this may be the case in the Hudson River Estuary. However, statistically significant amounts of phenanthrene mineralization were observed at all times and locations sampled. Thus, microbial degradation probably remains an important factor in low molecular weight PAH removal throughout the year.

The trends of phenanthrene degradation in the Hudson River resemble those for naphthalene in the Tamar Estuary, England (Readman et al. 1982). The rate of naphthalene degradation reached a maximum of $2 \mu \mathrm{g}$ $\mathrm{l}^{-1} \mathrm{~d}^{-1}\left(75 \% \mathrm{~d}^{-1}\right)$ in the urban region of the Tamar Estuary which had a salinity of $25 \mathrm{ppt}$ and declined toward riverine and marine waters. Naphthalene mineralization rates in CEPEX enclosure experiments ranged from $0.04 \mu \mathrm{g} \mathrm{l}^{-1} \mathrm{~d}^{-1}\left(0.2 \% \mathrm{~d}^{-1}\right)$ on Day 1 of the experiment to $3.3 \mu \mathrm{g} \mathrm{l}^{-1} \mathrm{~d}^{-1}\left(6.6 \% \mathrm{~d}^{-1}\right)$ by the third day (Lee \& Anderson 1977). The rates of naphthalene degradation observed in the present study are higher than those measured in some uncontaminated sediment systems. Herbes \& Schwall (1978) found that in uncontaminated sediments less than $0.2 \mathrm{ng} \mathrm{d}^{-1}$ ( $\mathrm{g}$ wet weight sediment $)^{-1}$ of initially added naphthalene was mineralized in $24 \mathrm{~h}\left(2.4 \% \mathrm{~d}^{-1}\right)$. Naphthalene mineralization rates in salt marsh sediments located near the Long Island Sound site used in the present study ranged from 1 to $4 \mu \mathrm{g} \mathrm{d}^{-1}$ per $\mathrm{g}$ dry wt of sediment ( 1 to $4 \% \mathrm{~d}^{-1}$ ) with a 1 to $3 \mathrm{~d}$ lag period (Bauer \& Capone $1985 b)$.

The poor relationship between bacterial abundance and PAH biodegradation potential further suggests that the composition of the bacterioplankton population and not total biomass is important in determining biodegradation rates. Bartholomew \& Pfaender (1983) found no relationship between $\mathrm{m}$-cresol biodegradation and direct microscopic counts in estuarine water samples. Sewage microorganisms generally degrade organic pollutants more efficiently with increasing metabolic activity, provided they are acclimated to the compound and that levels are not high enough to be toxic (Hickman \& Novak 1984). The present study indicates that high bacterial production rates are likely to coincide with high biodegradation rates in estuarine environments as well.

Our results also allow some useful observations on the general ecology of estuarine bacteria. It is interesting to note that in this study, bacterial abundance appeared to be regulated within a fairly narrow range, despite large differences in bacterial production over space and time. Because abundance is a result of the balance between bactreial production and whatever processes lead to removal of bacteria (e.g. grazing by larger organisms including protozoans, infection by phage or lytic bacteria, possibly other causes of cell lysis, and physical mixing with water of lower bacterial abundance), this apparent regulation suggests to us a close relationship between production and removal. The nature of this relationship is currently unknown, and its elucidation presents a challenge for future research.

Acknowledgements. We thank B. Deck, E. Carpenter, and J. Cheng for help on the Hudson River, and D. Capone and R. Kerr for helpful discussions. This work was supported by the Hudson River Foundation.

\section{LITERATURE CITED}

Bartholomew, G. W., Pfaender, F. K. (1983). Influence of spatial and temporal variations on organic pollutant biodegradation rates in an estuarine environment. Appl, environ. Microbiol. 45: 103-109

Bauer, J. E., Capone, D. G. (1985a). Effects of four aromatic organic pollutants on microbial glucose metabolism and thymidine incorporation in marine sediments. Appl. environ. Microbiol. 49: 828-835

Bauer, J. E., Capone, D. G. (1985b). Degradation and mineralization of the polycyclic aromatic hydrocarbons anthracene and naphthalene in intertidal marine sediments. Appl environ. Microbiol. 50: 81-90

Brown, M. P., Werner, M. B., Sloan, R. J. (1985). Polychlorinated biphenyls in the Hudson River. Environ. Sci. Technol. 19: 656-661

Buckley, E. N., Jones, R. B., Pfaender, F. K. (1976). Characterization of microbial isolates from an estuarine ecosystem: Relationship of hydrocarbon utilization to ambient hydrocarbon concentrations. Appl. environ. Microbiol. 32: 232-237

Connell, D. W. (1982). An approximate petroleum hydrocarbon budget for the Hudson Raritan Estuary-New York. Mar. Pollut. Bull. 13: 89-93

Cooney, J. J., Silver, S. A., Beck, E. A. (1985). Factors influencing hydrocarbon degradation in three freshwater lakes. Microb. Ecol. 11: 127-137

DeLaune, R. D., Gambrell, R. P., Reddy, K. S. (1983). Fate of pentachlorophenol in estuarine sediment. Environ. Pollut. Ser. B 6: 297-308

Ferguson, R. L., Buckley, E. N., Palumbo, A. V (1984). Response of marine bacterioplankton to differential filtration and confinement. Appl. environ. Microbiol. 47: 49-55

Fuhrman, J. A., Azam, F. (1982). Thymidine incorporation as a measure of heterotrophic bacterioplankton production in marine surface waters: evaluation and field results. Mar Biol. 66: 109-120

Herbes, S. E., Schwall, L. R. (1978). Microbial transformation of polycyclic aromatic hydrocarbons in pristine and petroleum contaminated sediments. Appl, environ. Microbiol. 35: 306-316

Hickman, G. T., Novak, J. T (1984). Acclimation of activated sludge to pentachlorophenol. J. Wat. Pollut. Control Fed. 56: $364-369$ 
Hobbie, J. E., Daley, R. J., Jasper, S. (1977). Use of Nuclepore filters for counting bacteria by fluorescence microscopy. Appl. environ. Microbiol. 33: 1225-1228

Huggett, R. J., Bender, M. E. (1980). Kepone in the James River. Environ. Sci. Technol. 14: 918-923

Knap, A. H., Williams, P. J., Tyler, I. (1979). Contribution of volatile petroleum hydrocarbons to the organic carbon budget of an estuary. Nature, Lond. 279: 517-519

Lee, R. F., Anderson, S. W. (1977). Fate and effect of naphthalene: controlled ecosystem pollution experiment. Bull. mar Sci. 27: 127-134

Lee, S., Fuhrman, J. A. (1987). Relationships between biovolume and biomass of naturally derived manine bacterioplankton. Appl. environ. Microbiol. 53: 12981303

Malone, T C. (1976). Phytoplankton productivity in the apex of the New York Bight: environmental regulation of productivity/chlorophyl a. In: Gross, M. G. (ed.) Middle Atlantic continental shelf and the New York Bight. American Society of Limnology and Oceanography, Spec. Symp. 2, p. 260-272

Mueller, J. A., Gerrish, T A., Casey, M. C. (1982). Contaminant inputs to the Hudson-Raritan Estuary. NOAA Technical Memorandum OMPA-21 Boulder, Colorado

Neff, J. M. (1979). Polycyclic aromatic hydrocarbons in the aquatic environment. Sources, fates, and biological effects. Applied Sciences Publishers, England

O'Connor, J. M., Klotz, J. B., Kneip, T. J. (1982). Sources, sinks, and distribution of organic contaminants in the New York Bight ecosystem. In: Mayer, G. F. (ed.) Ecological stress and the New York Bight: science and management. Estuarine Research Federation, Columbia, South Carolina, p. $631-653$

O'Connor, D. J., Mueller, J. A. (1984). Water quality analysis of New York Harbor complex. J. environ. Engineering 110: $1027-1047$

Pierce, R. H., Victor, D. M. (1978). The fate of pentachlorophenol in an aquatic system. In: Rao, K. R. (ed.) Pentachlorophenol. Plenum Press, New York, p. 41-52

Pignatello, J. J., Martinson, M. M., Steirt, J. G., Carlson, R. E., Crawford, R. L. (1983). Biodegradation of pentachlorophenol in artificial freshwater streams. Appl, environ. Microbiol. 46: 1024-1031

Readman, J. W., Mantoura, R. F. C., Rhead, M. M., Brown, L. (1982). Aquatic distribution and heterotrophic degradation of polycyclic aromatic hydrocarbons (PAH) in the Tamar Estuary. Estuar. coast. Shelf Sci. 14: 369-389

Roubal, G., Atlas, R. M. (1978). Distribution of hydrocarbonutilizing microorganisms and hydrocarbon biodegradation potentials in Alaskan continental shelf areas. Appl environ. Microbiol. 35: 897-905

Sherril, T W., Sayler, G. S. (1980). Phenanthrene biodegradation in freshwater environments. Appl. environ. Microbiol. 39: 172-178

Walker, J. D., Colwell, R. R. (1975). Some effects of petroleum on estuarine and marine microorganisms. Can. J. Microbiol. 21: 305-313

Ward, D. M., Brock, T. D. (1976). Environmental factors influencing the rate of hydrocarbom oxidation in temperate lakes. Appl. environ. Microbiol. 31: 764-772

This article was presented by Dr N. S. Fisher; it was accepted for printing on May 10, 1988 